\title{
APLIKASI PARADIGMA KONSTRUKTIVISTIK MODEL KOOPERATIF STAD UNTUK MENINGKATKAN KUALITAS PEMBELAJARAN PAI DI KELAS IV SD TARUNA SURABAYA
}

\author{
Hanik Yuni Alfiyah \\ (Magister Pendidikan Dasar UNY; Dosen FAI Unsuri \\ Surabaya)
}

\begin{abstract}
Abstrak:
Tulisan ini merupakan hasil penelitian tindakan kelas yang bertujuan untuk meningkatkan kualitas pembelajaran PAI siswa kelas IV SD Taruna Surabaya melalui aplikasi paradigm pembelajaran konstruktivis model kooperatif STAD. Subjek penelitian adalah siswa kelas IVB yang terdiri dari 42 siswa. Tahap-tahap penelitian meliputi perencanaan, tindakan, observasi, dan refleksi dalam dua siklus. Data dikumpulkan melalui wawancara, observasi, tes, catatan lapangan dan dokumentasi.

Wawancara dilakukan untuk memperoleh informasi tentang pendapat guru dan siswa mengenai proses pembelajaran; observasi dilakukan untuk memperoleh data tentang aktivitas siswa dalam kerja kelompok; tes dilakukan untuk mengukur pemahaman konsep siswa terhadap materi yang yang telah dipelajari; catatan lapangan dilakukan untuk memberikan gambaran proses pembelajaran yang terjadi; dan dokumentsi digunakan untuk mengetahui data tentang pemahaman konsep siswa pada pra tindakan. Data kualitatif dianalisis secara deskriptif kualitatif melalui tahapan koleksi data, reduksi data, display dan konklusi. Data kuantitatif dianalisis secara deskriptif kuantitatif dengan penyajian tabel dan dideskripsikan serta diambil kesimpulan berdasarkan kriteria yang mengacu pada rumus
\end{abstract}


yang dikembangkan oleh Saifuddin Azwar. Untuk menghindari subjektivitas dari observer, maka dilakukan trianggulasi.

Hasil penelitian menunjukkan bahwa kualitas pembelajaran PAI siswa kelas IV SD Taruna Surabaya meningkat melalui aplikasi paradigma pembelajaran konstruktivistik berupa pembelajaran kooperatif tipe STAD dengan langkah-langkah pembelajaran antara lain: 1) menyampaikan tujuan pembelajaran, 2) menyajikan informasi seputar skenario pembelajaran, 3) mengelompokkan siswa secara heterogen 4-5 siswa dalam kelompok, 4) membimbing siswa dalam kelompok, 5) melakukan evaluasi, dan 6) memberikan penghargaan kelompok.

Kata Kunci: PAI dan Pembelajaran Kooperatif Tipe STAD

\section{A. Pendahuluan}

Dalam Permendiknas N0. 22 Tahun 2006 dijelaskan bahwa agama diajarkan kepada manusia dengan visi untuk mewujudkan manusia yang bertaqwa kepada Allah SWT. dan berakhlaq mulia, serta bertujuan untuk menghasilkan manusia yang jujur, adil, berbudi pekerti, etis, saling menghargai, disiplin, harmonis dan produktif, baik personal maupun sosial. ${ }^{1}$ Tuntutan visi ini mendorong dikembangkannya standar kompetensi sesuai dengan jenjang pendidikan yang secara nasional ditandai dengan lebih menitikberatkan pada pencapaian kompetensi secara utuh -disamping penguasaan materi; mengakomodasikan keragaman kebutuhan dan sumber daya pendidikan yang tersedia; dan memberikan kebebasan yang lebih luas kepada pendidik di lapangan untuk

${ }^{1}$ Permendiknas N0. 22 Tahun 2006

Jurnal Pendidikan Agama Islam

Volume 02 Nomor 02 November 2014

Hal $234-272$ 
mengembangkan strategi dan program pembelajaran sesuai dengan kebutuhan dan ketersediaan sumber daya pendidikan.

Pendidikan agama Islam (PAI) diharapkan mampu menghasilkan manusia yang selalu berupaya menyempurnakan iman, taqwa, dan akhlaq, serta aktif membangun peradaban dan keharmonisan kehidupan, khususnya dalam memajukan peradaban bangsa yang bermartabat. Manusia seperti itu diharapkan tangguh dalam menghadapi tantangan, hambatan, dan perubahan yang muncul dalam pergaulan masyarakat, baik dalam lingkup lokal, nasional, regional maupun global.

Pada jenjang pendidikan tertentu, PAI diharapkan mampu untuk: 1) menumbuhkembangkan aqidah melalui pemberian, pemupukan, dan pengembangan pengetahuan, penghayatan, pengamalan, pembiasaan, serta pengalaman peserta didik tentang agama Islam sehingga menjadi manusia Muslim yang terus berkembang keimanan dan ketaqwaannya kepada Allah SWT; 2) mewujudkan manusia Indonesia yang taat beragama dan berakhlaq mulia, yaitu manusia yang berpengetahuan, rajin beribadah, cerdas, produktif, jujur, adil, etis, berdisiplin, bertoleransi (tasamuh), menjaga keharmonisan secara personal dan sosial serta mengembangkan budaya agama dalam komunitasnya.

Mata pelajaran PAI dalam kurikulum sekolah, disamping mandiri menjadi mata pelajaran, juga perlu menjadi bagian integral dari mata pelajaran lain yang diarahkan untuk menyiapkan peserta didik untuk mengenal, memahami, menghayati dan mengamalkan hukum Islam, yang kemudian menjadi dasar pandangan hidupnya (way of life) melalui kegiatan bimbingan, pengajaran, latihan, penggunaan pengalaman, pembiasaan dan keteladanan.

Mata pelajaran PAI, antara lain, meliputi: Al-QuranHadits, Aqidah-Akhlaq, Fiqih, Sejarah Kebudayaan Islam. Hal ini 
menggambarkan bahwa ruang lingkup PAI mencakup perwujudan keserasian, keselarasan, dan keseimbangan hubungan manusia dengan Allah SWT., dengan diri sendiri, sesama manusia, makhluk lainnya, dan lingkungannya (hablun minallah, hablun minannas, wa hablun minal 'alam).

Tuntutan tersebut di atas mengilhami pentingnya pembelajaran PAI yang harus dilakukan secara inovatif dan kreatif oleh para pendidik, terutama di sekolah umum. Hal itu penting karena didasarkan pada realitas pembelajaran di sekolah umum, yakni PAI di sekolah umum pada struktur kurikulum pendidikan sebagaimana dalam Permendiknas N0. 22 Tahun 2006 hanya dialokasikan sebanyak 2 jam pelajaran/minggu, dan kondisi riil proses pembelajaran PAI yang cenderung menjenuhkan. ${ }^{2}$ Selama ini, proses pembelajaran PAI di sekolah cenderung didominasi pembelajaran yang bersifat konvensional. Pembelajaran yang menjadi tradisi hanya memberikan informasi atau materi dalam bentuk instan. Siswa menerima informasi atau materi dari guru dengan cara menghafal informasi berupa konsepkonsep atau prinsip-prinsip baru tanpa adanya sinkronisasi pada konsep-konsep yang telah ada dalam struktur kognitifnya sehingga terjadi apa yang disebut sebagai belajar hafalan.

Terkait dengan permasalahan di atas adalah kondisi pembelajaran PAI di kelas IV SD Taruna Surabaya. Berdasarkan studi pendahuluan (pra survei), model pembelajaran PAI yang diterapkan di kelas IV SD Taruna Surabaya kurang dapat mengaktifkan siswa dalam proses pembelajaran. Siswa hanya menerima materi dan latihan soal dari guru. Hal itu tidak cukup mendukung penguasaan terhadap konsep PAI menjadi lebih baik. Dalam proses pembelajaran, sering hanya guru yang aktif

\footnotetext{
2 Permendiknas N0. 22 Tahun 2006
} 
menerangkan, sementara para siswa ramai, tidak memperhatikan penjelasan materi ajar dari guru.

Salah satu faktor kendala yang ada adalah strategi pembelajaran yang konvensional dan berefek pada ketidakefektifannya. Pembelajaran yang terjadi cenderung berbentuk ceramah, formalitas, pemberian tugas, dan kurang terarah pada kegiatan belajar bersama atau kegiatan belajar dengan pendekatan "siswa menemukan sendiri" konsep mata pelajaran. Guru kurang memiliki strategi khusus dalam memposisikan siswa agar aktif dan partisipatif dalam proses pembelajaran.

Pembelajaran konvensional dengan metode ceramah seperti yang terapkan pada siswa kelas IV SD Taruna Surabaya dinilai kurang efektif dalam meningkatkan kualitas pembelajaran. Inovasi yang kreatif dalam pembelajaran PAI amat dibutuhkan di sekolah, demi mencapai pembelajaran PAI yang aktif, inovatif, kreatif, efektif, menyenangkan, dan Islami (PAIKEMI). Dengan demikian perlu ada modifikasi pembelajaran PAI dalam prosesnya agar mencapai proses pembelajaran yang Paikemi.

Salah satu pendekatan dalam pembelajaran yang dapat menuju ke arah Paikemi adalah paradigma pembelajaran kostruktivistik, dimana pendidik berasumsi bahwa peserta didik dapat mengkostruk (membangun) pengetahuannya sendiri. Pendekatan konstruktivistik bersifat student-centered (berpusat pada peserta didik) dalam proses pembelajaran, dan berbeda dengan pendekatan behavioristik yang bersifat teacher-centered (berpusat pada pendidik) dalam proses pembelajaran.

Banyak model pembelajaran dengan paradigma konstruktivistik, salah satunya adalah pembelajaran kooperatif 
tipe STAD. ${ }^{3}$ Pembelajaran dengan pendekatan kolaborasi Tipe STAD merupakan tipikal pembelajaran yang berparadigma konstruktivistik, dan ini berbeda dengan pembelajaran yang bersifat konvensional yang lebih menekankan pada hafalan serta cenderung mematikan daya nalar dan kreativitas berpikir siswa. Dalam pembelajaran, guru hendaknya memilih strategi yang melibatkan siswa aktif, baik secara mental, fisik maupun sosial. Dalam hal ini, pembelajaran koperatif dengan model STAD dapat dijadikan sebagai salah satu strategi untuk meningkatkan pembelajaran aktif (active learning). ${ }^{4}$

Pembelajaran kooperatif tipe STAD merupakan bagian dari strategi pengejawantahan dari pembelajaran aktif. Pembelajaran aktif (active learning) dapat berfungsi untuk mengembangkan kemampuan berpikir tingkat tinggi, mengembangkan keterampilan psikomotorik, mengembangkan keterampilan kognitif, dan mengembangkan kemampuan akademik sekaligus keterampilan sosial. 5 Oleh karena itu, penerapan pembelajaran aktif dapat dijadikan model percontohan bagi pembelajaran yang dapat meningkatkan kualitas pembelajaran baik dari segi proses maupun hasil belajar. Dalam penelitian ini pembelajaran aktif yang berparadigma konstruktivistik dalam bentuk kooperatif tipe STAD dijadikan ramuan dalam penelitian tindakan kelas demi menyelesaikan masalah pembelajaran PAI yang pasif dan berkualitas rendah.

3 Nur Asma, Model pembelajaran kooperatif (Jakarta: Depdiknas Dirjen Dikti Dirket, 2006). Lihat juga Anita Lie, Cooperative Learning, Cet. VI, (Jakarta: Grasindo, 2008).

4 R. E. Slavin, Cooperative Learning: A Theory, Research and Practice, Second Edition (London: Allyn and Bacon, 1995). Lihat juga Mohamad Nur, Pembelajaran Kooperatif, (Surabaya: UNESA, 2005).

${ }^{5}$ Muslim Ibrahim, Pembelajaran Aktif, Makalah, (Surabaya: PPs UNESA, 2008), 6-10. 


\section{B. Rumusan Masalah}

Bagaimanakah meningkatkan kualitas pembelajaran PAI siswa kelas IV SD Taruna Surabaya melalui aplikasi paradigma pembelajaran konstruktivistik berupa kooperatif tipe STAD?

\section{Metode Penelitian}

Penelitian ini merupakan penelitian tindakan kelas (classroom action research). Pemilihan metode penelitian tindakan kelas didasarkan atas dasar masalah dan tujuan penelitian yang menuntut adanya penyempurnaan (tindak lanjut) berdasarkan prinsip daur ulang secara reflektif, kolaboratif, dan partisipatif yang dipusatkan pada situasi sosial kelas.

Penelitian tindakan kelas merupakan penelitian yang dilakukan sebagai strategi pemecahan masalah dengan memanfaatkan tindakan nyata, kemudian melakukan refleksi terhadap hasil tindakan. ${ }^{6}$ Hasil dari refleksi tersebut dijadikan sebagai langkah pemilihan tindakan berikutnya sesuai dengan permasalahan yang dihadapi. Dengan demikian, penelitian tindakan kelas dapat juga dinyatakan sebagai kegiatan reflektif terhadap permasalahan, kemudian mencari pemecahan masalah dengan melakukan tindakan nyata yang diperhitungkan dapat memecahkan masalah tersebut. Sebagaimana pernyataan Kemmis \& Mc. Taggart:

"Action research is a form of collective self-reflective enquiry undertaken by participants in social situation in order improve the rationality and justice of their own social

${ }^{6}$ Sukamto, dkk., Penelitian Tindakan, (Yogyakarta: Lemlit UNY, 2000). 
educational practices, as well as their understanding of these are carried out."7

Penelitian ini dilakukan di SD Taruna Surabaya pada mata pelajaran PAI. Subjek dalam penelitian ini adalah siswa kelas IVB dengan jumlah siswa sebanyak 42 orang. Pemilihan siswa kelas IVB dilakukan secara purposive, yakni subjek penelitian ditentukan sendiri dengan memilih salah satu kelas yang memiliki kualtas belajar rendah.

Dalam penelitian ini pengumpulan data dilakukan dengan menggunakan beberapa teknik sebagai berikut.

1. Observasi, teknik ini digunakan untuk mengumpulkan data mengenai unjuk aktivitas belajar siswa selama pengembangan tindakan dalam pembelajaran PAI berlangsung dengan menggunakan paradigma pembelajaran konstruktivistik berupa pembelajaran kooperatif tipe STAD.

2. Tes, teknik ini digunakan untuk mengukur hasil belajar PAI siswa, khususnya mengenai penguasaan terhadap materi pokok bahasan yang diajarkan dengan menggunakan paradigma pembelajaran konstruktivistik berupa pembelajaran kooperatif tipe STAD. Instrumen yang digunakan adalah soal yang terdiri dari pilihan ganda yang dibuat oleh peneliti bersama guru.

3. Dokumentasi, teknik ini digunakan untuk menjaring data mengenai jumlah siswa dan hasil belajar siswa pada semester sebelumnya sebagai dasar untuk menentukan jumlah kelompok dan pengelompokan dalam pembelajaran kooperatif dengan tipe STAD.

4. Wawancara tidak terstruktur, teknik ini digunakan untuk menjaring data yang berkaitan dengan pendapat guru dan

\footnotetext{
${ }^{7}$ Stephen Kemmis \& Mc., Robin Taggart, The Action Research Planner (Victoria: Deakin University Press, 1988).

Jurnal Pendidikan Agama Islam

Volume 02 Nomor 02 November 2014

Hal $240-272$
} 
siswa serta kepala sekolah tentang pelaksanaan pembelajaran di kelas IV SD Taruna Surabaya sebelum dan sesudah dilakukan pembelajaran kooperatif tipe STAD. Instrumen yang digunakan adalah pedoman wawancara yang berisi pokok-pokok/topik sebagai pegangan dalam pembicaraan. Topik-topik pembicaraan antara lain: pengalaman belajar atau mengajar, pendapat, pandangan atau tanggapan, dan perasaan siswa atau guru.

5. Catatan lapangan, digunakan untuk menjaring data mengenai kondisi kelas selama proses pembelajaran berlangsung.

Adapun instrumen yang digunakan dalam penelitian ini adalah:

1. Lembar observasi. Observasi akan dilakukan oleh peneliti. Observasi dalam penelitian ini adalah observasi langsung yaitu peneliti melihat dan mengamati secara langsung kemudian mencatat perilaku dan kejadian yang terjadi pada keadaan yang sebenarnya. Observasi dilakukan selama proses pembelajaran dari kegiatan awal sampai kegiatan akhir.

2. Lembar tes tertulis. Soal tes digunakan untuk mengetahui peningkatan hasil belajar PAI setelah diadakan pembelajaran kooperatif tipe STAD. Hasil tes yang diperoleh juga digunakan untuk mengetahui kemampuan siswa sehingga peneliti dapat merencanakan tindakan yang akan diambil dalam memperbaiki proses pembelajaran.

Penelitian ini dilakukan dalam bentuk siklus, masingmasing siklus terdiri dari beberapa komponen, yaitu tahap persiapan, perencanaan, pelaksanaan tindakan, observasi dan monitoring, refleksi, evaluasi dan revisi, dan kesimpulan hasil. Prosedur penelitian tindakan yang diterapkan dalam 
Hanik Yuni Alfiyah

penelitian ini dapat dilihat pada langkah-langkah penelitian yang diilustrasikan dalam siklus sebagai berikut.

\section{Dialog Awal}

Refleksi awal antara pendidik dan peneliti terhadap permasalahan pembelajaran

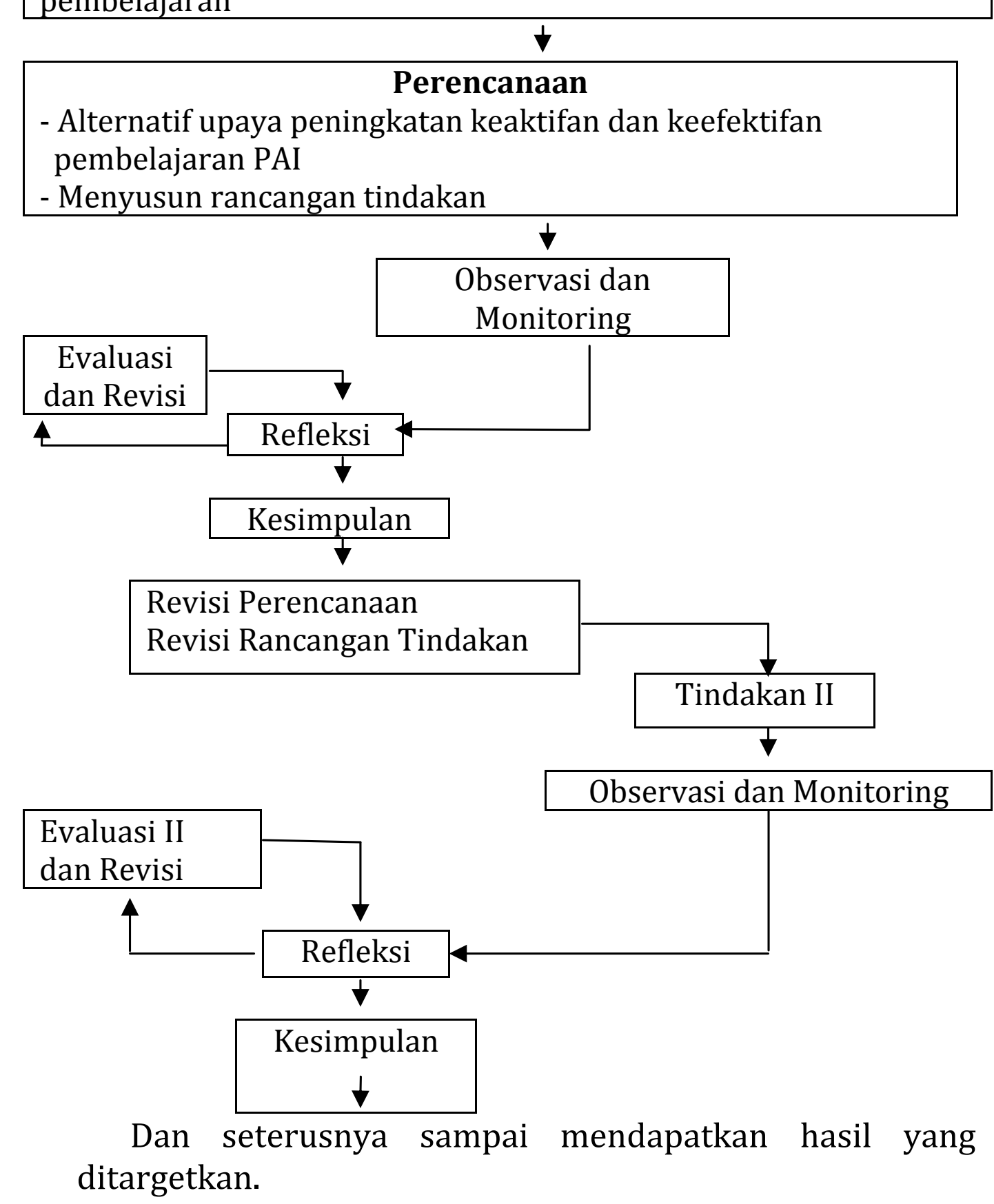

Gambar 1

Gambaran Umum Prosedur Penelitian

Jurnal Pendidikan Agama Islam

Volume 02 Nomor 02 November 2014

Hal $242-272$ 
Analisis data dalam penelitian ini dilakukan dengan cara merefleksi hasil observasi terhadap proses pembelajaran yang dilaksanakan oleh guru dan siswa di kelas. Data yang berupa kata-kata atau kalimat dari catatan lapangan diolah menjadi kalimat-kalimat yang bermakna dan dianalisis secara deskriptif kualitatif. Teknik ini mengacu pada model analisis dari Miles dan Huberman, yang dilakukan dalam komponen berurutan: koleksi data, reduksi data, penyajian data, dan penarikan kesimpulan. ${ }^{8}$

Data tentang aktivitas belajar siswa selama proses pembelajaran diperoleh dari hasil observasi pada awal dan akhir pembelajaran serta pada saat diskusi dan presentasi selama pembelajaran berlangsung. Data tersebut dianalisis secara deskriptif kuantitatif dengan penyajian tabel dan dideskripsikan serta diambil kesimpulan tentang masingmasing komponen dan indikator berdasarkan kriteria yang ditentukan. Penentuan kriteria mengacu pada rumus yang dikembangkan oleh Saifuddin Azwar. ${ }^{9}$ Rentang skor untuk masing-masing kategori dihitung sebagaimana rumus pada tabel sebagai berikut.

\section{Tabel 1}

Kriteria Penilaian Aktivitas Belajar Siswa

\begin{tabular}{|c|c|}
\hline$(\mathrm{M}+1,50 \mathrm{~s})<\mathrm{X}$ & Sangat baik \\
\hline$(\mathrm{M}+0,50 \mathrm{~s})<\mathrm{X} \leq(\mathrm{M}+1,50 \mathrm{~s})$ & Baik \\
\hline$(\mathrm{M}-0,50 \mathrm{~s})<\mathrm{X} \leq(\mathrm{M}+0,50 \mathrm{~s})$ & Cukup \\
\hline$(\mathrm{M}-1,50 \mathrm{~s})<\mathrm{X} \leq(\mathrm{M}-0,50 \mathrm{~s})$ & Kurang \\
\hline $\mathrm{X} \leq(\mathrm{M}-1,50 \mathrm{~s})$ & Sangat kurang \\
\hline
\end{tabular}

8 B. M. Miles \& Huberman, Qualitative Data Analysis (London: SAGE Publications, 1984), 22

${ }_{9}^{9}$ Saifuddin Azwar, Tes Prestasi (Yogyakarta: Pustaka Relajar, 2007), 63. 
Hanik Yuni Alfiyah

Keterangan: $\quad M \quad=$ Mean

$$
\begin{array}{ll}
\mathrm{S} & =\text { Standar deviasi } \\
\mathrm{X} & =\text { Skor }
\end{array}
$$

Data hasil tes belajar PAI siswa dianalisis menggunakan rumus sebagai berikut:

Jumlah jawaban benar X 100

Jumlah seluruh soal

Untuk mendapatkan validitas data, dalam penelitian ini digunakan teknik triangulasi, yaitu pemeriksaan data dengan memanfaatkan sesuatu yang ada di luar data itu (chek and rechek; periksa dan periksa kembali). Triangulasi dalam penelitian ini dilakukan dengan sebuah metode, yaitu dengan melakukan pengecekan ulang informasi dari pengamatan dan tes akhir setiap siklus tindakan dengan menggunakan metode yang sama. ${ }^{10}$

\section{Profil SD Islam Tarbiyatul Athfal}

SD Islam Tarbiyatul Athfal adalah sebuah Sedolah Dasar yang berada di bawah naungan yayasan pendidikan Islam tarbiyatul Ulumun Nahdliyah (Taruna) yang beralamatkan di Jln. Mejoyo I/2 Kelurahan Kalirungkut, kecamat Rungkut, kota Surabaya. Status sekolah tersebut adalah swasta dan terakreditasi A. Adapun visi sekolah tersebut adalah mencetak generasi penerus bangsa yang beriman dan bertakwa kepada Allah SWT serta cerdas, terampil, berakhlak mulia, tanggap dan mantap dalam menyongsong masa depan penuh rasa percaya diri sekaligus terwujudnya penyelenggaraan pendidikan yang berkualitas serta berwawasan ke Islaman dan kebangsaan.

10 B. M. Miles \& Huberman, Qualitative Data Analysis, 434. 
SD Taruna memiliki beberapa misi, antara lain adalah: (1) Menanamkan dasar keimanan dan ketakwaan yang kuat dalam kehidupan keluarga, masyarakat, bangsa, dan negara; (2) Memberikan dasar keterampilan hidup, baik bidang ilmu pengetahuan umum dan teknologi serta agama; (3) Membentuk kepribadian peserta didik yang beriman, bertakwa dan berakhlak mulia; (4) Menumbuhkan dasar kemahiran membaca, menulis dan berhitung yang mampu memecahkan masalah dan berfikir logis, kritis serta kreatif; (5) Mewujudkan sistem pembelajaran yang berkualitas dan mengcu kurikulum berbasis kompetensi dengan memanfaatkan sumber daya yang memadai.

Sedangkan tujuannya antara lain: (1) Memberikan bekal kepada siswa untuk memahami dan berperilaku sesuai dengan ajaran agama Islam; (2) Meningkatkan kualitas pendidik sesuai sesuai dengan tuntutan zaman era globalisasi; Meningkatkan ilmu pengetahuuan dan teknologiyang sesuai dengan kemampuan siswa untuk berpikir logis, krestif dsn kritis; dan (4) Menjalin kerjasama atrar instansi terkait dalam peningkatan mutu pendidikan.

Dalam perkembangan lima tahun tertakhir, jumlah siswa di SD Taruna terus mengalami peningkatan. Data tersebut sebagaimana disajikan pada tabel berikut.

\section{Tabel 2}

Jumlah Siswa SD Taruna pada Lima Tahun Terakhir

\begin{tabular}{|c|c|c|c|}
\hline \multirow{2}{*}{ Tahun } & \multicolumn{2}{|c|}{ Jenis Kelamin } & \multirow{2}{*}{ Jumlah } \\
\cline { 2 - 3 } & $\mathbf{L}$ & $\mathbf{P}$ & \\
\hline $2005 / 2006$ & 190 & 178 & 368 \\
\hline $2006 / 2007$ & 200 & $172 /$ & 372 \\
\hline $2007 / 2008$ & 184 & 179 & 363 \\
\hline $2008 / 20009$ & 186 & 171 & 357 \\
\hline $2009 / 2010$ & 197 & 181 & 378 \\
\hline
\end{tabular}


SD Taruna Surabaya memiliki 23 orang guru yang terdiri dari 21 orang guru tetap, dan 2 orang guru tidak tetap. Adapun fasilitas yang dimilikinya antara lain: 6 ruang kelas secara umum berkondisi baik, 1 ruang guru, 1 ruang kepala sekolah, 1 ruang perpustakaan, 1 ruang tata usaha, 1 ruang laboratorium IPA dan Matematika, 1 ruang Usaha Kesehatan Sekolah, 1 ruang Bimbingan dan Penyuluhan/Bimbingan dan Konseling, 1 ruang musholla, 1 ruang laboratorium komputer, serta 5 kamar mandi/WC. ${ }^{11}$

\section{E. Hasil Penelitian}

\section{Pra Tindakan}

Pra tindakan merupakan kondisi nyata yang berhubungan dengan aktifitas belajar dan pemahaman konsep PAI siswa kelas IV SD Taruna Surabaya pada saat sebelum dilakukannya tindakan. Kondisi mengenai aktifitas belajar siswa didapatkan melalui wawancara yang dilakukan oleh peneliti terhadap guru mata pelajaran PAI di kelas tersebut. Sedangkan data mengenai pemahaman konsep PAI siswa pada pra tindakan didapatkan melalui dokumentasi sekolah, yaitu hasil ulangan harian siswa.

Berdasarkan hasil wawancara yang dilakukan oleh peneliti kepada guru, ia menyatakan bahwa aktifitas belajar siswa dalam mata pelajaran PAI dinilai kurang memuaskan. Yang mana hal ini berimplikasi pada pemahaman konsep siswa terhadap mata pelajaran PAI tersebut. Berdasarkan data ulangan harian siswa dalam mata pelajaran PAI, diketahui bahwa sebagian besar siswa masih memiliki nilai yang rendah. Berikut disajikan data ulangan harian siswa pada pra tindakan.

11 Dokumen Profil SDI Taruna Surabaya, Tahun 2010. 


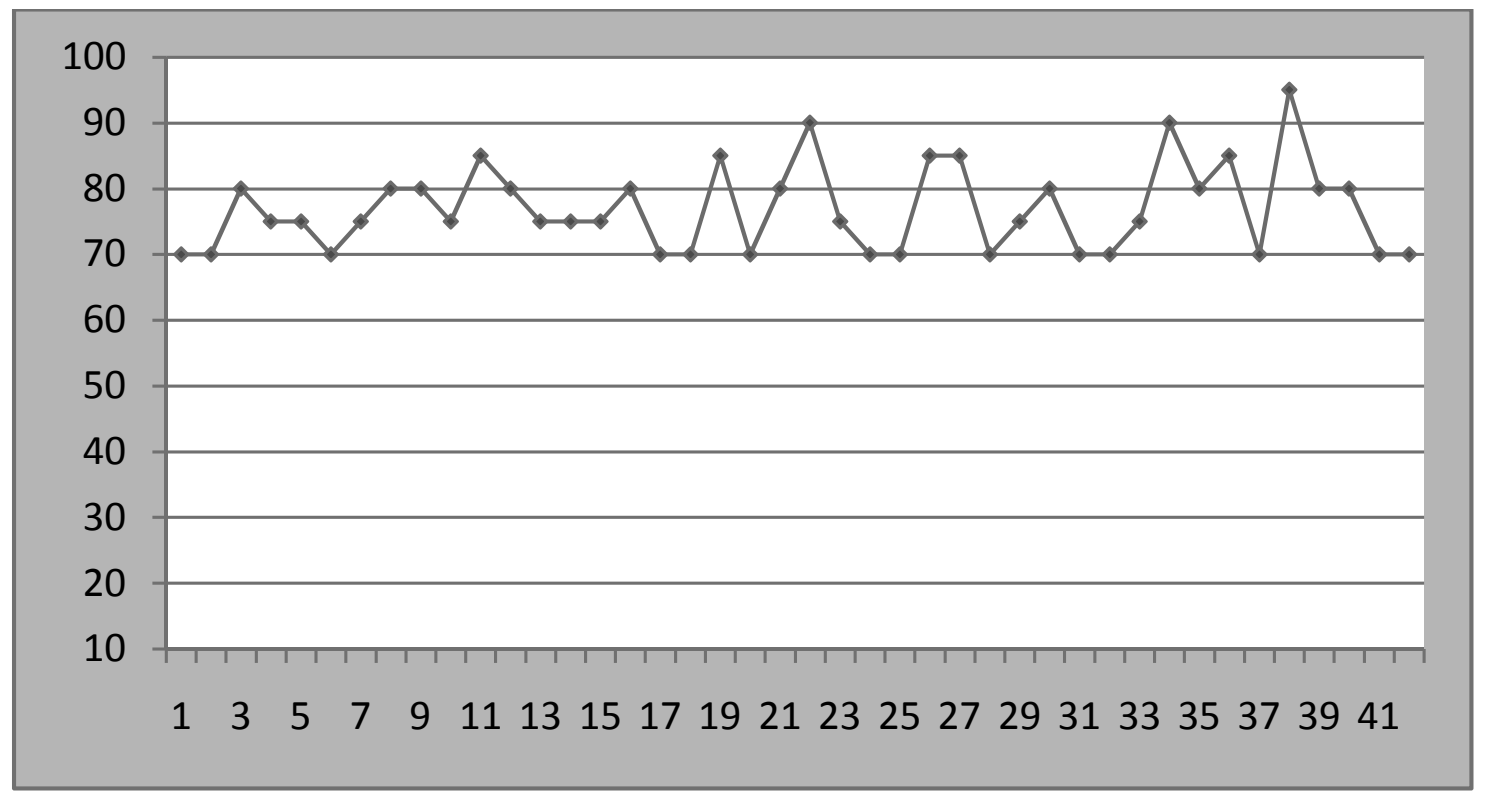

\section{Gambar 3}

\section{Data Pemahaman Konsep Siswa Pra Tindakan}

Data tersebut di atas menunjukkan bahwa pada kondisi pra tindakan, pemahaman konsep siswa terhadap materi pelajaran PAI yang telah diajarkan oleh guru belum menunjukkan hasil yang optimal. Hal ini terindikasi dari kenyataan bahwa banyak siswa yang masih memiliki nilai sesuai atau setara dengan standar minimal nasional mata pelajaran PAI, yaitu 7,0.

\section{Siklus I}

\section{a. Perencanaan dan Tindakan}

Sebelum pelaksanaan tindakan, perencanaan dilakukan sebagai upaya penyusunan langkah-langkah yang akan dilakukan selama proses pembelajaran. Langkah-langkah yang dimaksud antara lain adalah menentukan materi yang akan diberikan, membuat skenario pembelajaran, membentuk kelompok belajar siswa, dan membuat instrumen. 
Hanik Yuni Alfiyah

Adapun materi yang diberikan pada siklus I adalah ketentuan-ketentuan shalat. Kompetensi dasar yang akan dicapai dari materi tersebut adalah menyebutkan rukunrukun shalat. Sementara itu indikator dari kompetensi tersebut antara lain: (1) Dapat menyebutkan rukunrukun shalat; (2) Dapat mempraktikkan gerakan/posisi yang termasuk rukun shalat; (3) Dapat mengaplikasikan dalam ibadah shalat. Adapun skenario pembelajaran yang telah disusun dan digunakan dalam pembelajaran siklus I adalah sebagaimana yang disajikan dalam tabel 3.

Dalam proses pembelajaran, siswa dibagi menjadi sepuluh kelompok. Tiap kelompok beranggotakan 4-5 orang siswa yang memiliki kemampuan akademik dan jenis gender yang heterogen. Hal tersebut dimaksudkan agar dalam kegiatan diskusi kelompok siswa yang memiliki kemampuan lebih tinggi dapat membantu siswa lain yang memiliki kemampuan lebih rendah. Begitu pula sebaliknya, siswa yang memiliki kemampuan akademik lebih rendahpun mendapatkan motivasi, bantuan dan dorongan akademik dari siswa yang berkemampuan akademik lebih tinggi. Sementara itu, instrumen penelitian dikembangkan untuk mengukur aktivitas siswa dalam kegiatan diskusi kelompok, serta untuk mengukur pemahaman siswa terhadap materi pelajaran yang telah dipelajari. 


\section{Tabel 3}

\section{Skenario Pembelajaran Siklus I}

\begin{tabular}{|l|l|}
\hline \multicolumn{1}{|c|}{ Kegiatan Guru } & \multicolumn{1}{c|}{ Kegiatan Siswa } \\
\hline $\begin{array}{l}\text { Membuka pembelajaran, } \\
\text { menyampaikan tujuan } \\
\text { pembelajaran, memotivasi } \\
\text { siswa, dan menyampaikan } \\
\text { apersepsi }\end{array}$ & Menyimak ceramah guru \\
\hline $\begin{array}{l}\text { Menjelaskan secara singkat } \\
\text { materi rukun-rukun shalat }\end{array}$ & Menyimak ceramah guru \\
\hline $\begin{array}{l}\text { Mempersilahkan siswa } \\
\text { mendiskusikan materi } \\
\text { rukun-rukun shalat serta } \\
\text { gerakan/posisinya bersama } \\
\text { teman kelompok, Serta } \\
\text { membimbing siswa dalam } \\
\text { kegiatan diskusi tersebut }\end{array}$ & $\begin{array}{l}\text { Berdiskusi kelompok mengenai } \\
\text { rukun-rukun shalat serta } \\
\text { gerakan/posisinya }\end{array}$ \\
\hline $\begin{array}{l}\text { Mempersilahkan perwakilan } \\
\text { kelompok siswa untuk } \\
\text { mempresentasikan hasil } \\
\text { diskusinya }\end{array}$ & $\begin{array}{l}\text { Mempresentasikan hasil } \\
\text { diskusi, yaitu menunjukkan } \\
\text { gerakan/posisi yang termasuk } \\
\text { Mengevaluasi kerja siswa, } \\
\text { memberikan tes tulis, } \\
\text { menyimpulkan, serta } \\
\text { menutup pembelajaran. }\end{array}$ \\
$\begin{array}{l}\text { Mengerjakan tes tulis dan } \\
\text { menutup pembelajaran. }\end{array}$ \\
\hline
\end{tabular}

Proses pembelajaran diawali dengan guru membuka pembelajaran dan menyampaikan tujuan pembelajaran serta kompetensi dasar yang berkaitan dengan materi pembelajaran. Meski demikian, sebelum pembelajaran dilakukan guru menjelaskan metode dan pendekatan yang akan diterapkan selama proses 
pembelajaran berlangsung. Setelah itu guru menyampaiakan tata cara siswa melakukan kegiatan pembelajaran tersebut.

Untuk menyiasati agar siswa tertarik terhadap proses pembelajaran PAI dengan pendekatan konstruktivis model kooperatif tipe STAD, guru menyampaikan manfaat dari penerapan pendekatan tersebut, antara lain, bahwa siswa dapat menyadari manfaat diskusi yang diterapkan bagi masyarakat sekitar, dan ia akan dapat berperan aktif dalam menyelesaikan masalah atau kesulitan yang dialami masyarakat di sekitarnya melalui media diskusi. Dengan model seperti itu diharapkan siswa akan terlibat aktif dalam diskusi kelompok dalam pembelajaran materi PAI. Selanjutnya guru mempersilahkan siswa untuk menanyakan hal-hal yang kurang difahami mengenai tata cara model pembelajaran PAI dengan pendekatan konstruktivis model kooperatif tipe STAD.

Pembelajaran dilanjutkan dengan guru memberikan penjelasan mengenai rukun-rukun shalat. Setelah itu guru mempersilahkan siswa untuk mendiskusikan materi tersebut bersama temaan kelompoknya. Dalam kegiatan diskusi, siswa mendiskusikan tentang rukun-rukun shalat, dengan cara saling memberi pemahaman mengenai rukun-rukun shalat tersebut, kemudian kegiatan dilanjutkan dengan saling menghafal. Dalam kegiatan saling menghafal, setiap siswa berusaha menghafalkan hal-hal yang termasuk rukun-rukun shalat secara mandiri. Sebagian siswa melakukannya dengan memejamkan mata sambil mulutnya berkomat-kamit, dan sesekali membuka matanya untuk melihat buku, sebagian yang lain 
menghafalkannya dengan cara membacanya berulangulang.

Setelah kegiatan menghafalkan, kegiatan dilanjutkan dengan saling mengoreksi hasil hafalan antar anggota kelompok. Kegiatan saling mengoreksi yang dimaksud adalah kegiatan dimana seorang siswa menyebutkan hal-hal yang termasuk rukun-rukun shalat dengan tanpa melihat buku di depan teman kelompoknya, sedang siswa yang lain mengoreksi apa yang diucapkan oleh temannya. Apakah temannya tersebut telah menyebutkan rukun-rukun shalat dengan benar, ataukah tidak. Setelah kegiatan saling mengoreksi, siswa melanjutkan kegiatan dengan mendiskusikan gerakan atau posisi hal-hal yang termasuk rukun shalat.

Jadi setiap siawa diharapkan dapat mengetahui bagaimana gerakan-gerakan atau posisi-posisi rukunrukun shalat tersebut. Dalam kegiatan diskusi tersebut guru senantiasa terus memantau kegiatan siswa dan membimbing setiap kelompok dalam melakukan kegiatan diskusi dengan cara mengunjungi setiap kelompok secara bergantian. Dalam kunjungan dan bimbingannya tersebut, guru memperhatikan jalannya kegiatan diskusi yang dilakukan oleh siswa, kemudian memberikan penjelasan mengenai hal-hal yang tidak dipahami oleh kelompok siswa.

Setelah kegiatan diskusi, pembelajaran dilanjutkan dengan kegiatan presentasi yang dilakukan oleh setiap anggota atau perwakilan kelompok. Dalam kegiatan presentasi ini, setiap kelompok mengutus satu anggota kelompoknya untuk mempresentasikan hasil diskusinya mengenai rukun-rukun shalat, terutama pada gerakangerakan atau posisi-posisi yang termasuk rukun shalat. 
Dalam kergiatan presentasi, sluruh siswa diperkenankan untuk mengajukan pertanyaan, ataupun memberikan penambahan penjelasan mengenai hal-hal yang telah dipresentasikan oleh temannya. Setelah kegiatan presentasi, guru bersama siswa-siswa lainnya mengevaluasi hasil presentasi yang telah dilakukan oleh temannya.

Setelah seluruh siswa selesai melakukan kegiatan presentasi, guru mengevaluasi seluruh kegiatan pembelajaran yang telah dilalui pada hari itu. Guru menyampaikan hal-hal yang dianggap kurang memenuhi target dalam kegiatan pembelajaran, serta hal-hal yang dapat dibanggakan dalam kegiatan pembelajaran. Hal ini dimaksudkan untuk memberikan rasa senang dan lebih termotivasi pada diri siswa, sehingga mereka akan tetap bersemangat dan tidak berputus asa dengan kekurangankekurangan yang telah terjadi.

Kemudian guru memberikan tes tulis yang berisi tentang materi rukun-rukun shalat kepada siswa. Dalam hhal ini siswa diminta untuk mengerjakan soal-soal tersebut secara mandiri. Pemberian tes tersebut bertujuan untuk mengetahui sejauh mana siswa telah memahami materi rukun-rukun shalat. Pada akhir kegiatan, guru memberikan kesimpulan mengenai materi pelajaran yang telah dipelajari, dan menutup pembelajaran dengan doa dan salam.

\section{b. Hasil Observasi}

\section{Aktifitas Belajar Siswa}

Berdasarkan hasil observasi, diketahui bahwa siswa terlihat sangat senang dan antusias selama proses pembelajaran. Hampir seluruh siswa merespon 
positif terhadap tindakan yang diberikan. Respon positif siswa terindikasi oleh sikap dan perilaku siswa selama proses pembelajaran. Terlebih lagi saat kegiatan diskusi kelompok dan presentasi. Dalam kegiatan diskusi kelompok, seluruh siswa melakukannya dengan semangat, mulai dari menghafalkan rukun-rukun shalat, saling mengoreksi, sampai kegiatan mempraktikkan gerakan-gerakan dan posisi-posisi rukun shalat. Rasa senang dan semangat siswa terindikasi dari ekspresi wajah mereka yang menampakkan keceriaan serta sikap dan tingkah laku mereka yang terus aktif selama kegiatan pembelajaran. Tidak jarang dari mereka yang tertawa ketika kegiatan diskusi kelompok, terlebih lagi ketika melihat salah satu temannya yang mempresentasikan gerakan dan posisi shalat, sehingga proses pembelajaran terkesan seperti permainan.

Namun demikian, terdapat pula sebagian siswa yang masih terlihat bingung, malu dan ragu ketika melakukan kegiatan presentasi di depan kelas. Hal tersebut dilatar belakangi oleh faktor ketidak terbiasaan siswa dalam melakukan kegiatan pembelajaran dengan model kooperatif tipe STAD, terutama dalam kegiatan presentasi di depan kelas. Aktfitas siswa dalam diskusi cukup tinggi, walaupun sebagian siswa masih kesulitan untuk mengemukakan pendapatnya karena mereka masih merasa malu dan belum terbiasa dengan model pembelajaran yang digunakan. Pada saat kegiatan presentasi sedang berlangsung, sebagian siswa yang menjadi delegasi mengatakan, "malu, bu!", dan sebagainya. Meski demikian, guru tidak bosan memberikan empati untuk 
Hanik Yuni Alfiyah

meredakan keluh kesah siswa serta memotivasi siswa untuk tidak malu dan ragu dalam dalam menyampaikan presentasi di depan kelas.

Adapun aspek-aspek yang diamati selama kegiatan diskusi kelompok terdiri dari lima aspek, antara lain: keaktifan dalam kerja kelompok, menjalin komunikasi dan berinteraksi, bekerjasama dan saling memberikan refleksi, menghargai kontribusi dan bersikap obejektif, dan bertanggungjawab dalam mengemukakan pendapat. Adapun hasil observasi yang telah dilakukan terhadap aktivitas siswa selama kegiatan diskusi kelompok pada siklus I disajikan pada tabel 4 sebagai berikut.

Tabel 4

Data Aktivitas Siswa dalam Diskusi Kelompok pada Siklus I

\begin{tabular}{|c|c|c|c|}
\hline No. & Kategori & Frekuensi & Persentase (\%) \\
\hline 1. & Sangat aktif & - & $0 \%$ \\
\hline 2. & Aktif & 25 & $59,52 \%$ \\
\hline 3. & Cukup & 11 & $26,19 \%$ \\
\hline 4. & Pasif & 6 & $14,29 \%$ \\
\hline 5. & Sangat pasif & - & $0 \%$ \\
\hline \multicolumn{2}{|c|}{ Jumlah } & $\mathbf{4 2}$ & $\mathbf{1 0 0 \%}$ \\
\hline
\end{tabular}

Tabel 4 menunjukkan bahwa pada siklus I terdapat 59,58 siswa yang terlibat aktif dalam proses pembelajaran, terutama dalam krgiatan diskusi kelompok. Berikut disajikan trend perkembangan persentase siswa yang terlibat aktif dalam proses pembelajaran, terutama dalam kegiatan diskusi 
kelompok selama siklus I disajikan pada gambar 4 berikut.

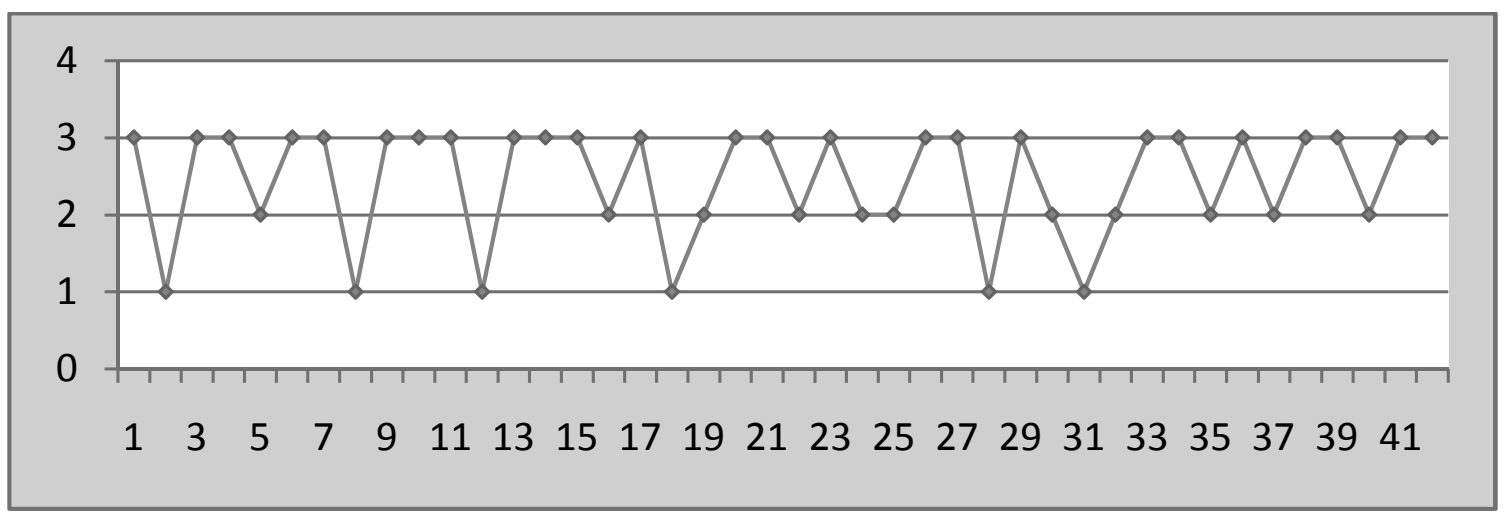

\section{Gambar 4}

Data Aktifitas Siswa dalam Diskusi Kelompok pada Siklus I

Keterangan: 4 = Sangat aktif

$$
\begin{aligned}
& 3=\text { Aktif } \\
& 2=\text { Cukup } \\
& 1=\text { Pasif } \\
& 0=\text { Sangat pasif }
\end{aligned}
$$

Tampak pada gambar di atas, persentase siswa yang termasuk kategori aktif dalam kegiatan diskusi kelompok pada siklus I masih mencapai 59,52\%, sedangkan 40,48\% yang lainnya masih berada pada kategori cukup dan pasif. Apabila dikaitkan dengan kriteria keberhasilan penelitian, maka hasil tersebut dinyatakan belum memenuhi target.

\section{Pemahaman Konsep PAI}

Pemahaman konsep yang dimaksud adalah pemahaman siswa mengenai materi rukun-rukun shalat. Pemahaman konsep ini diketahui melalui hasil tes yang diberikan setelah pelaksanaan tindakan siklus I. Secara grafik, hasil tes pemahaman konsep siswa 
Hanik Yuni Alfiyah

terhaddap materi rukun-rukun shalat pada siklus I disajikan pada gambar 5 sebagai berikut.

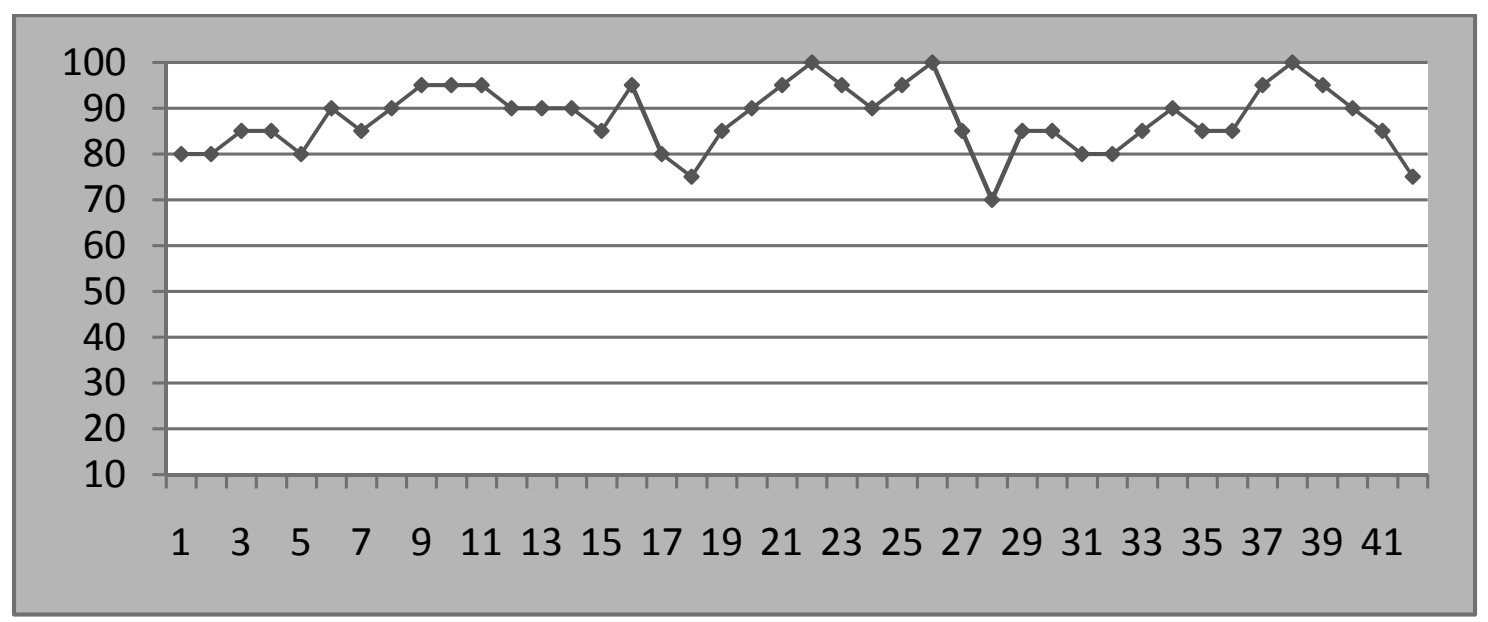

Gambar 5

Hasil Tes Siklus I

Gambar 5 menunjukkan bahwa, pada siklus I terdapat 33 siswa $(78,57 \%)$ yang telah memenuhi standar minimal yang telah ditentukan dalam penelitian ini yaitu dengan memiliki nilai $\geq 85$. Sedangkan 9 siswa lainnya (21,43\%) belum dapat memenuhi standar minimal yang telah ditentukan. Sehingga apabila berdasar pada kriteria keberhasilan tindakan penelitian ini, maka tindakan pada siklus I dinyatakan belum memenuhi kriteria keberhasilan yang telah ditentukan.

\section{c. Refleksi Tindakan pada Siklus I}

Pembelajaran pada siklus I difokuskan agar siswa dapat bekerja bersama dalam suatu kelompok kecil maupun besar dalam menyelesaikan berbagai permasalahan (tugas) yang diberikan. Penerapan pendekatan konstruktivis model kooperatif tipe STAD pada siklus I telah dapat dilakasanakan secara optimal. 
Hanya saja, sebagian siswa masih terlihat kesulitan melakukan sosialisasi dengan teman kelompoknya, dan dengan seluruh teman kelasnya dalam kegiatan presentasi. Hal tersebut dikarenakan ketidak terbiasaan siswa dengan pendekatan baru yang digunakan.

Hasil pemantauan dan evaluasi terhadap pelaksanaan pembelajaran pada siklus I pada bagian pendahuluan, guru terlebih dahulu menyampaikan apersepsi berupa pernyataan-pernyataan dan juga pertanyaan yang berkaitan dengan konsep sehingga siswa menjadi tertarik dan tertantang serta siap menerima dan terlibat dalam proses pembelajaran.

Setelah apersepsi, kegiatan inti pada pembelajaran ini adalah pemberian tugas kelompok yang harus dikerjakan dan didiskusikan siswa dalam kelompok, kemudian menyajikan hasil diskusi dalam presentasi kelas. Sementara itu pada akhir pembelajaran guru selalu menyimpulkan dan mengklarifikasi materi sebagai penguatan dan motivasi siswa untuk lebih giat lagi dalam memberikan kontribusi pemikiran pada kelompoknya.

Hasil observasi mengenai aktivitas siswa dalam kegiatan pembelajaran, siswa terlihat antusias dengan strategi pembelajaran yang dilaksanakan oleh guru. Walaupun awalnya siswa sedikit bingung mengikuti pola pembelajaran model ini. Dari hasil pemantauan beberapa kemampuan kerjasama, berinteraksi, dan menghargai kontribusi, sudah mulai muncul pada pelaksanaan pembelajaran siklus I. Analisis dan refleksi terhadap aktifitas siswa pada siklus I, menunjukkan bahwa indikator keberhasilan siswa yang meliputi aktif dalam kerja kelompok, kerjasama, menghargai kontribusi, menjalin komunikasi yang interaktif, dan bertanggug 
jawab dalam berpendapat, telah terpenuhi oleh sebagaian besar siswa.

Hal tersebut berdasarkan hasil observasi yang telah dilakukan pada pembelajaran siklus I, yang memberikan hasil bahwa 59,52\% siswa telah dapat terlibat aktif dalam proses pembelajaran terutama diskusi kelompok. Namun demikian, jumlah tersebut apabila bertolak pada kriteria keberhasilan tindakan dalam penelitian ini, yang mana telah ditetapkan bahwa tindakan akan dinyatakan berhasil apabila sekurangkurangnya $85 \%$ siswa telah dapat terlibat aktif dalam proses pembelajaran dengan memenuhi indikator yang telah ditetapkan.

Begitu pula dengan pemahaman konsep siswa, berdasarkan hsil tes yang telah diberikan, pada siklus I terdapat $78,57 \%$ yang telah memenuhi standar minimal yang telah ditentukan dalam penelitian ini yaitu dengan memiliki nilai $\geq 85$. Sehingga apabila berdasar pada kriteria keberhasilan tindakan penelitian ini, maka tindakan pada siklus I dinyatakan belum memenuhi kriteria keberhasilan yang telah ditentukan. Dengan demikian, maka kegiatan pembelajaran ini perlu dilanjutkan pada siklus berikutnya.

\section{Siklus II}

\section{a. Perencanaan dan Tindakan}

Sebelum pelaksanaan tindakan siklus II, guru dan peneliti melakukan diskusi sebagai upaya penyusunan langkah-langkah yang akan dilakukan selama proses pembelajaran siklus II. Penyusunan langkah-langkah pembelajaran diupayakan dapat menjawab permasalahan-permasalahan yang terjadi selama 
pembelajaran pada siklus I, serta mengupayakan hasil yang lebih optimal dari pada siklus I, sehingga pelaksanaan tindakan dapat mencapai kriteria keberhasilan yang lebih baik sebagaimana telah ditentukan.

Langkah-langkah yang dimaksud adalah menentukan materi yang akan diberikan, dan membuat skenario pembelajaran. Adapun materi yang akan diberikan pada siklus II adalah mengenal ketentuanketentuan shalat. Kompetensi dasar yang akan dicapai dari materi tersebut adalah mengetahui gerakan dan bacaan shalat. Sedangkan indikator dari kompetensi tersebut antara lain: (1) Dapat menjelaskan gerakangerakan shalat; (2) Dapat membacakan bacaan-bacaan shalat; (3) Dapat mempraktikkan shalat dengan lengkap. Adapun skenario pembelajaran yang telah disusun adalah sebagaimana yang disajikan pada tabel 5 .

\section{Tabel 5}

\section{Skenario Pembelajaran Siklus II}

\begin{tabular}{|l|l|}
\hline \multicolumn{1}{|c|}{ Kegiatan Guru } & \multicolumn{1}{c|}{ Kegiatan Siswa } \\
\hline $\begin{array}{l}\text { Membuka pembelajaran, } \\
\text { menyampaikan tujuan } \\
\text { pembelajaran, memotivasi } \\
\text { siswa, dan menyampaikan } \\
\text { apersepsi }\end{array}$ & $\begin{array}{l}\text { Menyimak ceramah } \\
\text { guru }\end{array}$ \\
\hline $\begin{array}{l}\text { Menjelaskan secara singkat } \\
\text { materi gerakan dan bacaan } \\
\text { dalam shalat }\end{array}$ & $\begin{array}{l}\text { Menyimak ceramah } \\
\text { guru }\end{array}$ \\
\hline $\begin{array}{l}\text { Mempersilahkan siswa } \\
\text { mendiskusikan materi }\end{array}$ & $\begin{array}{l}\text { Berdiskusi kelompok } \\
\text { mengenai gerakan dan }\end{array}$ \\
\hline
\end{tabular}




\begin{tabular}{|l|l|}
\hline $\begin{array}{l}\text { gerakan dan bacaan dalam } \\
\text { shalat bersama teman } \\
\text { kelompok, Serta } \\
\text { membimbing siswa dalam } \\
\text { kegiatan diskusi tersebut }\end{array}$ & bacaan dalam shalat \\
\hline $\begin{array}{l}\text { Mempersilahkan setiap } \\
\text { kelompok mempraktikkan } \\
\text { shalat secara bergantian di } \\
\text { depan kelas }\end{array}$ & $\begin{array}{l}\text { Mempraktikkan shalat } \\
\text { bersama teman } \\
\text { kelompok }\end{array}$ \\
\hline $\begin{array}{l}\text { Mengevaluasi kerja siswa, } \\
\text { memberikan tes tulis, } \\
\text { menyimpulkan, serta } \\
\text { menutup pembelajaran. }\end{array}$ & $\begin{array}{l}\text { Mengerjakan tes tulis } \\
\text { dan menutup } \\
\text { pembelajaran. }\end{array}$ \\
\hline
\end{tabular}

Pelaksanaan tindakan pada siklus II merupakan kelanjutan dari siklus I. Proses pembelajaran pada siklus I dinyatakan belum mencapai standar keberhasilan yang telah ditetapkan. Dengan demikian perlu dilanjutkan pada siklus berikutnya. Hasil refleksi pada siklus I menyatakan, belum berhasilnya tindakan secara optimal karena siswa masih belum terbiasa dengan pembelajaran yang menggunakan pendekatan konstruktivis model kooperatif tipe STAD, sehingga siswa masih sulit menjalin kerjasama antar sesama anggota kelompok dalam menyelesaikan tugas kelompok atau penyajian hasil tugas kelompok dalam presentasi kelas. Berdasarkan refleksi observasi dan penilaian pada siklus I, maka siklus II merupakan perbaikan daripada siklus I.

Pada siklus II, guru mencoba menerapkan pembelajaran lebih optimal. Artinya hal-hal yang menjadi penyebab belum optimalnya pembelajaran pada siklus I harus diperbaiki dengan memperhatikan aturan yang 
menjadi ketetapan dalam pendekatan yang digunakan. Pada awal pembelajaran, guru memulai dengan melakukan apersepsi. Apersepsi dilakukan untuk menarik minat siswa dengan memberikan kesempatan pada siswa untuk membahas hasil pembelajaran pada pertemuan sebelumnya, serta memberikan motivasi kepada siswa untuk senantiasa terlibat aktif dalam kegiatan diskusi kelompok, dan tidak malu ataupun ragu dalam kegiatan presentasi. Selain itu, guru juga memberikan penjelasan mengenai pembelajaran yang akan dilakukan pada pertemuan tersebut.

Pada kegiatan inti, guru mempersilahkan siswa mendiskusikan gerakan-gerakan dan bacaan-bacaan shalat sebagaimana yang telah tertulis dalam buku ajar bersama teman kelompoknya. Dalam kegiatan ini, siswa melakukan kegiatan saling membacakan dan saling mengoreksi bacaan-bacaan shalat bersama teman kelompoknya. Diharapkan dengan kegiatan tersebut siswa dapat terbiasa dengan bacaan-bacaan shalat tersebut, yang pada akhirnya siswa diharapkan dapat menghafalkannya.

Selain saling membacakan bacaan shalat, siswa juga berlatih dan mempraktikkan shalat secara lengkap bersama teman kelompoknya. Bagi siswa yang belum hafal dengan bacaan-bacaan shalat, diperkenankan untuk membawa teks yang berisi bacaan-bacaan shalat. Sehingga siswa melaksanakannya dengan tanpa keterpaksaan. Selama siswa menjalankan kegiatan diskusi kelompok, guru mengamati dan membimbing kerjasama siswa secara bergiliran. Dalam hal ini, mengunjungi dan membimbing kegiatan yang dilakukan siswa, serta membantu kelompok atau siswa yang mendapatkan 
Hanik Yuni Alfiyah

kesulitan.

Kegiatan selanjutnya adalah presentasi. Dalam kegiatan ini, setiap kelompok bersama seluruh anggota kelompoknya diminta untuk mempraktikkan gerakangerakan dan bacaan-bacaan shalat di depan kelas. Kegiatan mempraktikkan shalat ini dilakukan oleh setiap kelompok secara bergantian. Siswa memperagakan gerakan-gerakan shalat yang dimulai dari niat dan takbiratul ihram hingga salam, sambil membacakan bacaan-bacaan shalat dengan keras. Bagi siswa yang belum hafal, diperbolehkan membawa teks yang berisi bacaan shalat.

Pada saat satu kelompok mempraktikkan gerakan dan bacaan shalat di depan kelas, kelompok lain diminta untuk mengoreksi gerakan-gerakan dan bacaan-bacaan shalat yang dibacakan oleh kelompok yang mendapat giliran untuk maju. Dengan demikian, baik siswa yang mendapat giliran untuk maju, maupun yang tidak, akan tetap memfokuskan pikirannya pada kegiatan belajar. Selain itu, siswa juga terlatih untuk peka terhadap hal-hal yang disimaknya, dan mengajarkan siswa untuk memiliki sikap kritis serta berani untuk menyampaikan kekritisannya.

Setelah seluruh kelompok mempraktikkan gerakan dan bacaan shalat di depan kelas, guru dan siswa bersama-sama mengevaluasi kegiatan yang telah dilalui. Dan dilanjutkan dengan kegiatan mengerjakan soal-soal tes yang berkaitan dengan materi gerakan dan bacaan shalat. Sebelum akhir pembelajaran, guru menyimpulkan seluruh kegiatan pembelajaran yang telah dilalui dan menutupnya dengan doa dan salam. 


\section{b. Hasil Observasi}

\section{1) Aktivitas Belajar Siswa}

Berdasarkan hasil pengamatan yang dilakukan oleh peneliti dan observer selama pembelajaran pada siklus II, diperoleh kesimpulan bahwa pada siklus II, keaktifan siswa cukup tinggi, pembicaraan tidak lagi didominasi guru dan siswa tertentu, sebagimana pada siklus I. Hampir semua siswa memberikan kontribusi untuk kelompoknya. Kerjasama antar sesama siswa dalam kelompok yang sama sudah tampak pada setiap diskusi maupun presentasi. Perilaku siswa sudah meningkat seperti aktif dalam kelompok, menjalin komunikasi secara interaktif, mampu melakukan kerjasama, serta menghargai pendapat orang lain ketika kegiatan diskusi berlangsung.

Selain itu, siswa juga terlihat sangat antusias dan memiliki motivasi yang tinggi dalam mengikuti pembelajaran. Hal ini terlihat dari kemauan siswa untuk terlibat secara aktif dalam kegiatan diskusi kelompok yang menjadi tanggug jawabnya. Pada siklus II ini tidak terlihat siswa yang hanya duduk diam atau santai ataupun keluar kelas. Hal ini karena kesibukan siswa dalam menyelesaikan tugas-tugasnya. Bahkan sebagian besar siswa sudah berani memberi komentar, bertanya, bahkan memberi usul, kritik maupun saran kepada temannya. Sejalan dengan berkembangnya kemampuan kerjasama siswa, aktivitas siswa selama pembelajaran pun meningkat ke arah yang lebih baik. Kemajuan ini tidak terlepas dari meningkatnya usaha guru dalam merefleksi diri dari pengalaman sebelumnya. Hal ini ditunjukkan dari hasil observasi terhadap aktivitas siswa yang meningkat dari siklus sebelumnya. 
Aktivitas belajar siswa dalam siklus II mengalami peningkatan dari pada siklus I. Hampir seluruh siswa telah mampu memenuhi indikatorindikator yang telah ditetapkan, yaitu antara lain terlibat aktif dalam kerja kelompok, menjalin komunikasi dan berinteraksi, bekerjasama dan saling memberikan refleksi, menghargai kontribusi dan bersikap obejektif, dan bertanggungjawab dalam mengemukakan pendapat. Adapun hasil observasi yang telah dilakukan terhadap aktivitas siswa dalam diskusi kelompok pada siklus II dapat disajikan pada tabel 6 sebagai berikut.

Tabel 6

Data Aktivitas Siswa dalam Diskusi Kelompok pada Siklus II

\begin{tabular}{|c|c|c|c|}
\hline No. & Kategori & Frekuensi & $\begin{array}{c}\text { Persenta } \\
\text { se (\%) }\end{array}$ \\
\hline 1. & Sangat aktif & 16 & $38,09 \%$ \\
\hline 2. & Aktif & 24 & $57,14 \%$ \\
\hline 3. & Cukup & 2 & $4,77 \%$ \\
\hline 4. & Pasif & - & $0 \%$ \\
\hline 5. & Sangat pasif & - & $0 \%$ \\
\hline \multicolumn{2}{|c|}{ Jumlah } & $\mathbf{4 2}$ & $\mathbf{1 0 0 \%}$ \\
\hline
\end{tabular}

Tabel 6 menunjukkan bahwa pada siklus II terdapat 16 siswa $(38,09 \%)$ yang memiliki kategori sangat aktif dalam kegiatan diskusi kelompok, 24 siswa $(57,14 \%)$ yang memiliki kategori aktif dalam kegiatan diskusi kelompok, dan siswa $(4,77 \%)$ siswa berkategori cukup dalam kegiatan diskusi kelompok. 
Trend perkembangan aktivitas siswa selama siklus II dapat disajikan pada gambar 6 sebagai berikut.

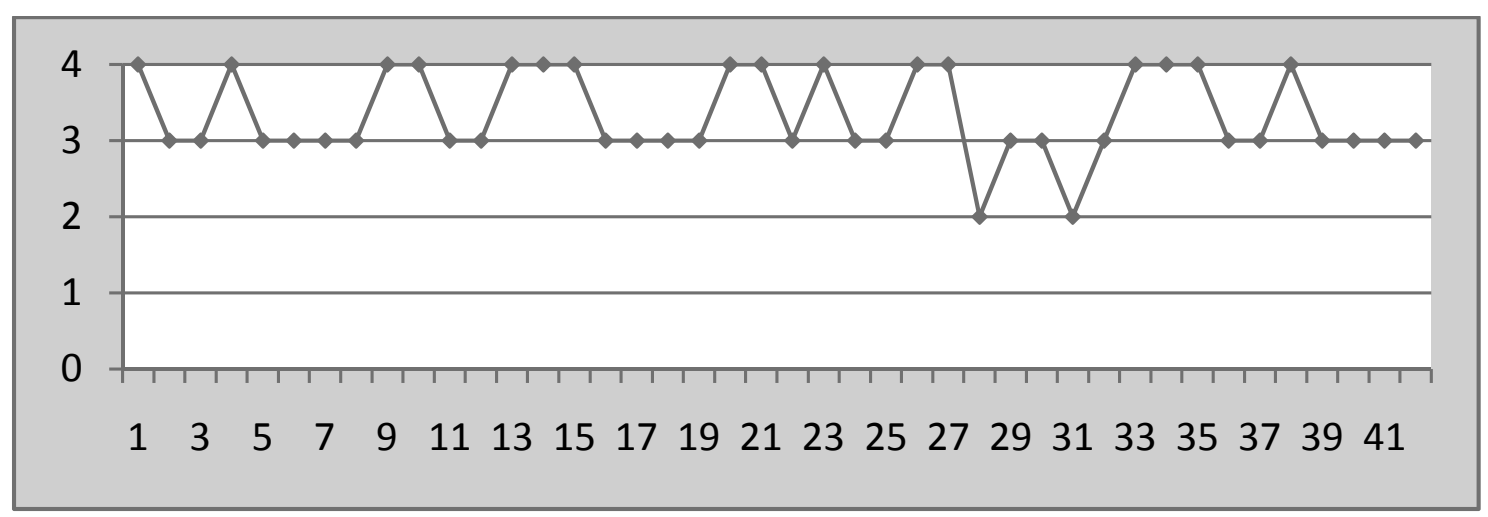

\section{Gambar 6}

Aktivitas Siswa dalam Diskusi Kelompok pada Siklus II

Keterangan: $4=$ Sangat aktif

$$
\begin{aligned}
& 3=\text { Aktif } \\
& 2=\text { Cukup } \\
& 1=\text { Pasif } \\
& 0=\text { Sangat pasif }
\end{aligned}
$$

Tampak pada gambar 6, persentase aktivitas siswa pada siklus II menunjukkan trend yang meningkat dari pada siklus I. Pada siklus II terdapat 40 (95,23\%) siswa yang terlibat aktif dalam kegiatan diskusi kelompok. Apabila dikaitkan dengan kriteria keberhasilan tindakan yang telah ditetapkan dalam penelitian ini,, tampak bahwa persentase untuk siklus II telah mencapai kriteria keberhasilan yang telah ditentukan, yakni $85 \%$ siswa aktif dalam kegiatan pembelajaran.

\section{2) Pemahaman Konsep PAI pada Siklus II}

Pemahaman konsep PAI siswa diukur melalui tes yang diberikan pada siswa pada akhir 
pembelajaran. Tes tersebut berisi tentang hal-hal yang berkaitan dengan materi gerakan dan bacaan shalat. Berdasarkan hasil penilaian terhadap hasil tes yang diberikan kepada siswa, diketahui bahwa pada siklus II telah terdapat $39(92,86 \%)$ siswa yang telah memiliki pemahaman konsep di atas standar minimal yang telah di tentukan, yaitu, 85\% siswa memiliki nilai di atas 85 . Secara grafik, pemahaman konsep PAI siswa pada siklus II disajikan pada gambar 7 sebagai berikut.

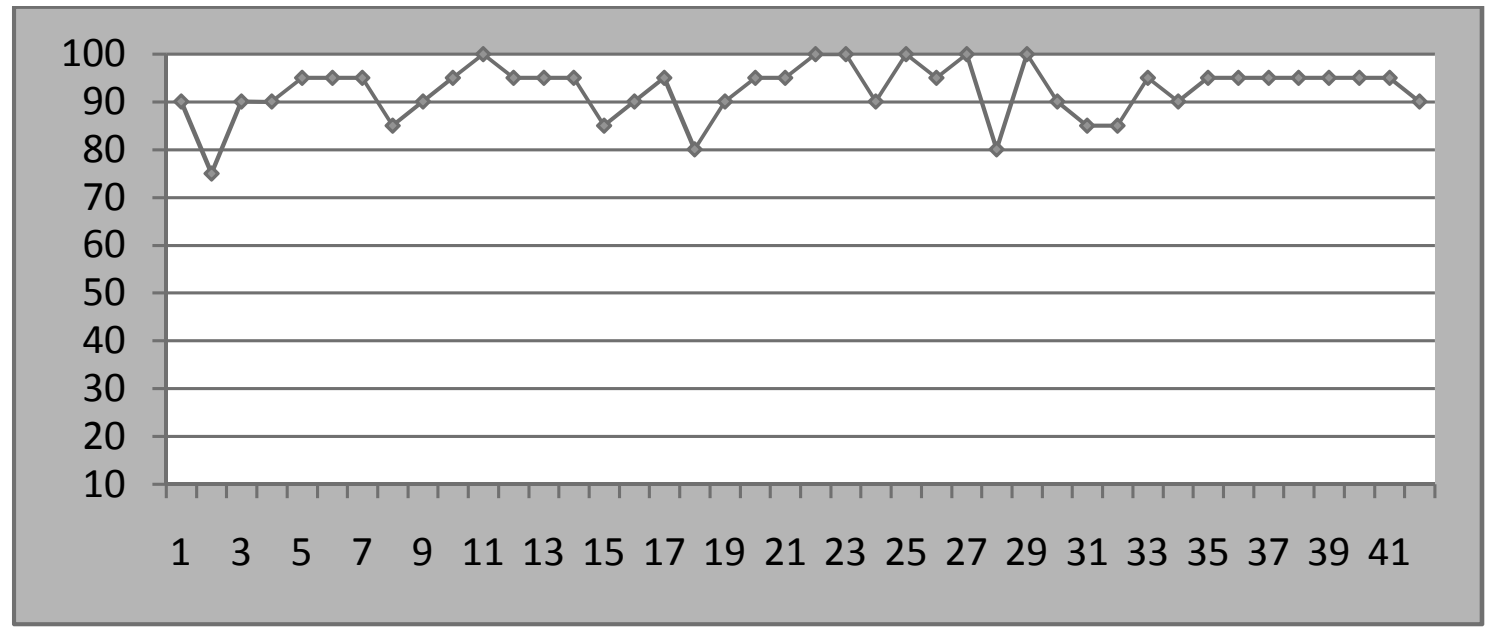

\section{Gambar 7}

Hasil Tes Siklus II

\section{e. Refleksi Tindakan pada Siklus II}

Pada siklus II, pembelajaran PAI dengan pendekatan konstruktivis mode kooperatif STAD ini dapat dikatakan berjalan secara optimal. Kenyataan ini terlihat dari aktivitas belajar siswa yang lebih tinggi dibandingkan dengan siklus sebelumnya. Indikator yang dapat dijadikan pijakan adalah meningkatnya pemahaman konsep dan aktivitas belajar siswa selama pelaksanaan tindakan pada siklus II sebagaimana terlihat pada gambar 6 dan gambar 7 . 
Berdasarkan pengamatan terhadap kegiatan pembelajaran pada siklus II, setiap awal pembelajaran guru melakukan apersepsi untuk memotivasi siswa. Selama kegiatan pembelajaran, guru selalu menciptakan situasi kondusif. Hal ini terlihat pada kegiatan inti pembelajaran, guru dapat mengelola kelas dengan baik. Pada saat kegiatan diskusi kelompok, guru mengamati dan memberikan bimbingan. Selanjutnya pada kegiatan penutup guru merangkum materi dan mengklarifikasi pelajaran sebagai penguatan dan melakukan tanya jawab.

Pada pelaksanaan siklus II ini, melalui kegiatan pembelajaran, siswa terlibat secara aktif dan dapat menguasai materi yang diajarkan dengan lebih baik. Aktivitas belajar siswa sangat tinggi dibandingkan dengan siklus sebelumnya, sehingga berimplikasi pada meningkatnya pemahaman konsep sesuai dengan yang diharapkan. Hasil pengamattan menunjukkan suasana pembelajaran lebih terfokus pada upaya siswa menjalin komunikasi dan kerjasama yang harmonis dalam upaya menyelesaikan permasalahan yang diberikan dan pemahaman konsep yang lebih baik.

Selama pembelajaran berlangsung, suasana kelas sangat hidup dan ramai oleh kegiatan siswa, mulai dari kegiatan saling membacakan bacaan-bacaan shalat, kemudian menghafalkannya, sampai pada kegiatan memperagakan/mempraktikkan shjalat yang dilakukan oleh setiap kelompok siswa di depan kelas. Analisis dan refleksi siklus II menunjukkan indikator keberhasilan siswa sudah terpenuhi. Artinya, bahwa proses dan hasil pembelajaran PAI sudah dapat tercapai dengan baik. Hal ini berarti bahwa, pelaksanaan tindakan berupa pembelajaran dengan pendekatan konstruktivis model 
kooperatif tipe STAD telah berhasil dan memenuhi indikator keberhasilan tindakan yang telah ditentukan dalam penelitian ini. Sehingga tindakan yang diberikan dalam penelitian ini telah dianggap cukup sampai siklus II.

Berdasarkan hasil wawancara yang diakukan secara terbuka dengan beberapa siswa pada akhir siklus II, terungkap bahwa sebagian besar siswa setuju dengan penerapan pembelajaran PAI dengan menggunakan pendekatan konstruktivis model kooperatif tipe STAD, karena siswa dapat memahami konsep PAI dengan lebih mudah, menarik, tidak membosankan dan komunikasi siswa lebih terjalin dengan lebih baik. Selanjutnya siswa mengharapkan agar metode pembelajaran tersebut terus diterapkan dalam pembelajaran PAI.

\section{F. Pembahasan}

\section{Aktivitas Belajar Siswa}

Aktivitas belajar siswa diamati dalam kegiatan diskusi kelompok. Berdasarkan hasil analisis terhadap hasil observasi aktivitas siswa dalam kegiatan diskusi kelompok selama dua siklus sebagaimana telah diuraikan di atas, maka trend perkembangan persentase siswa yang melakukan diskusi kelompok dapat disajikan pada gambar 8 sebagai berikut.

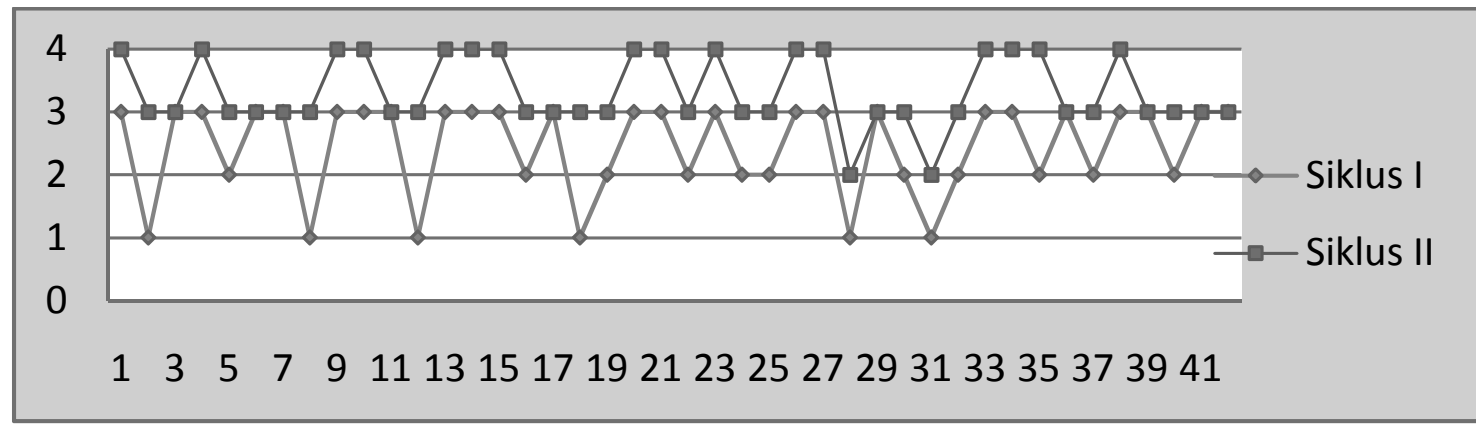

Gambar 8

Aktivitas Siswa dalam Diskusi Kelompok pada Siklus I dan II

Jurnal Pendidikan Agama Islam

Volume 02 Nomor 02 November 2014

Hal $268-272$ 


$$
\begin{array}{lll}
\text { Keterangan: } & 4=\text { Sangat aktif } & 1=\text { Pasif } \\
& 3=\text { Aktif } & 0=\text { Sangat pasif } \\
2 & =\text { Cukup } &
\end{array}
$$

Tampak pada gambar di atas, perkembangan keaktifan siswa dalam kegiatan diskusi kelompok menunjukkan trend yang meningkat dari siklus I ke siklus II. Realitas tersebut mengindikasikan bahwa siswa telah mampu bekerja sama dengan baik dengan teman kelompok, berperan aktif dalam kegiatan kelompok, menjalin komunikasi yang baik dengan para anggota kelompok, menghargai kontribusi yang diberikan oleh anggota kelompok lain selama kegiatan diskusi, serta bertanggung jawab atas tugas-tugas kelompok. Temuan ini memperkuat temuan-temuan sebelumnya yang menunjukkan bahwa pembelajaran kooperatif tipe STAD memang cocok dan sesuai untuk diterapkan dalam upaya peningkatan kualitas pembelajaran.

\section{Pemahaman Konsep PAI}

Berdasarkan deskripsi prestasi pemahaman konsep PAI siswa pada siklus I dan II sebagaimana telah diuraikan pada bagian sebelumnya, maka trend perkembangan nilai ulangan harian yang diperoleh siswa dapat disajikan pada gambar 9. 


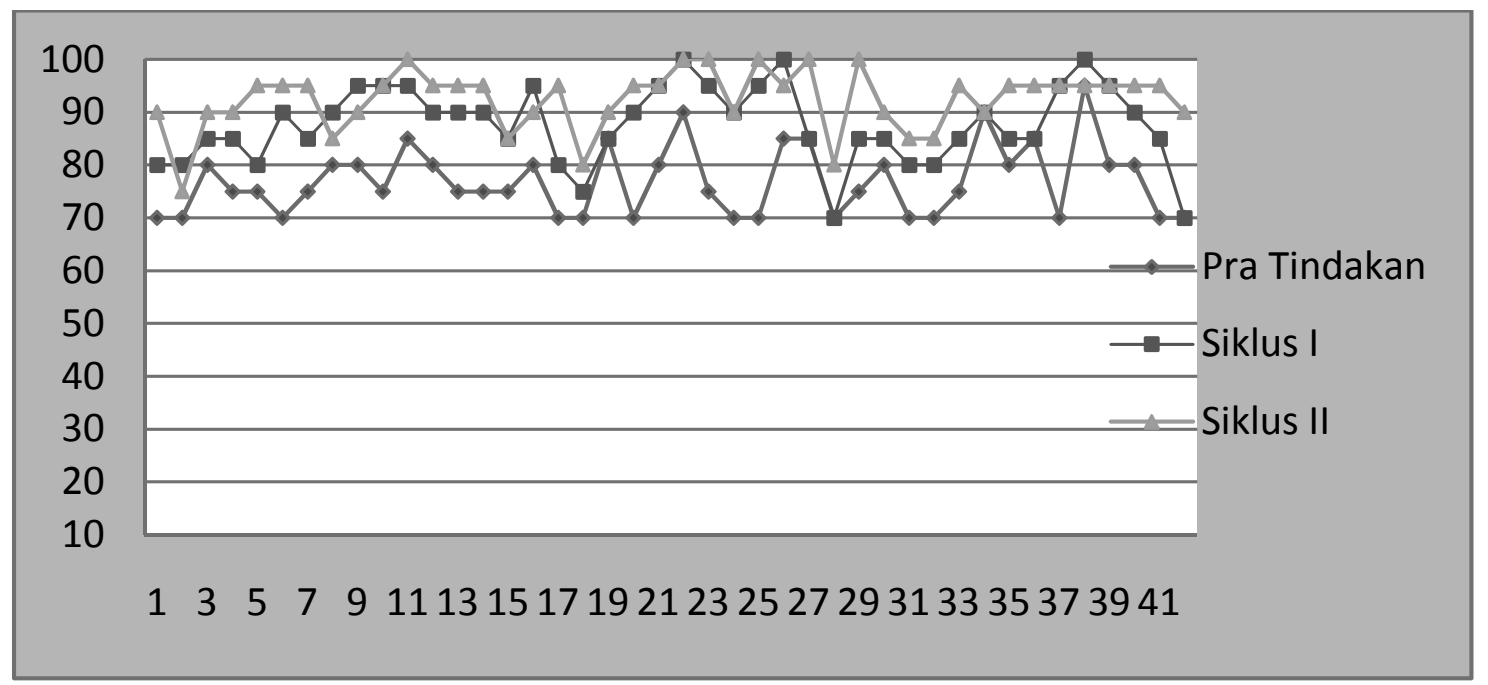

\section{Gambar 9}

Hasil Tes pada Pra Tindakan, Siklus I dan II

Pada gambar 9, tampak perkembangan nilai pemahaman konsep PAI siswa menunjukkan trend yang meningkat mulai dari kondisi pra tindakan, siklus I hingga siklus II. Pada akhir siklus II, peningkatan pemahaman konsep PAI yang diperoleh siswa sangat baik, yaitu 92,86\% siswa telah mencapai standar minimal yang telah ditentukan dalam penelitian ini, yaitu memiliki nilai $\geq 85$. Realitas tersebut juga mengindikasikan bahwa penerapan metode pembelajaran kooperatif tipe STAD pada pembelajaran PAI di SD Taruna Surabaya berhasil. Keberhasilan tersebut tentu tidak terlepas dari peran guru yang mampu mengaplikasikan prinsip yang mendasari model tersebut dalam kelas.

\section{Respon Siswa terhadap Penerapan Model Pembelajaran} STAD

Respon siswa terhadap penerapan pembelajaran dengan menggunakan pendekatan konstruktivis model kooperatif tipe STAD menunjukkan respon yang positif. Hal tersebut ditunjukkan dari hasil wawancara kepada beberapa 
siswa yang menunjukkan bahwa pada umumnya siswa merespon positif terhadap pembelajaran yang diberikan. Bahkan sebagian besar siswa meminta agar model pembelajaran seperti yang telah dilakukan dapat terus diterapkan di kelas mereka.

\section{G. Penutup}

Berdasarkan uraian di atas, dapat disimpulkan bahwa kualitas pembelajaran PAI siswa kelas IV SD Taruna Surabaya meningkat melalui aplikasi paradigma pembelajaran konstruktivistik berupa pembelajaran kooperatif tipe STAD dengan langkah-langkah pembelajaran antara lain: 1) menyampaikan tujuan pembelajaran, 2) menyajikan informasi seputar skenario pembelajaran, 3) mengelompokkan siswa secara heterogen 4-5 siswa dalam kelompok, 4) membimbing siswa dalam kelompok, 5) melakukan evaluasi, dan 6) memberikan penghargaan kelompok.

Kualitas pembelajaran PAI siswa kelas IV SD Taruna Surabaya semakin meningkat. Hal tersebut terlihat dari meningkatnya aktifitas belajar siswa yang ditandai oleh sikap dan perilaku siswa yang menjadi lebih aktif dan partisipatif serta merasa lebih senang dan termotivasi dalam belajar dari siklus I ke siklus II hingga mencapai kriteria keberhasilan yang telah ditentukan. Selain itu, pemahaman konsep PAI siswa juga meningkat mulai dari kondisi pra tindakan hingga akhir siklus II. Hal ini ditandai oleh kenyataan bahwa pada akhir siklus II, 92,86\% siswa telah mencapai standar minimal yang telah ditentukan dalam penelitian ini yaitu memiliki nilai ulangan harian $\geq 85$. 
Hanik Yuni Alfiyah

\section{DAFTAR PUSTAKA}

Asma, Nur, 2006, Model pembelajaran kooperatif, (Jakarta: Depdiknas Dirjen Dikti Dirket)

Azwar, Saifuddin, 2007, Tes Prestasi, (Yogyakarta: Pustaka Relajar)

Ibrahim, Muslim, 2008, Pembelajaran Aktif, Makalah, (Surabaya: PPs UNESA)

Kemmis, Stephen \& Mc., Robin Taggart, (1988), The Action Research Planner, (Victoria: Deakin University Press)

Miles, B.M. \& Huberman, 1984, Qualitative Data Analysis, (London: SAGE Publications)

Nur, Mohamad, 2005, Pembelajaran Kooperatif, (Surabaya: UNESA)

Permendiknas N0. 22 Tahun 2006

Sukamto, dkk., 2000, Penelitian Tindakan, (Yogyakarta: Lemlit UNY)

Slavin, R. E., 1995, Cooperative Learning: A Theory, Research and Practice, Second Edition, (London: Allyn and Bacon) 